\title{
Prevention of toxin-induced cytoskeletal disruption and apoptotic liver cell death by the grapefruit flavonoid, naringin
}

\author{
H Blankson ${ }^{1}$, EM Grotterød ${ }^{1}$ and PO Seglen ${ }^{\star, 1}$ \\ 1 Department of Cell Biology, Institute for Cancer Research, The Norwegian \\ Radium Hospital, Montebello, N-0310 0slo, Norway \\ * Corresponding author: PO Seglen, Department of Cell Biology, Institute for \\ Cancer Research, The Norwegian Radium Hospital, Montebello, N-0310 Oslo, \\ Norway, Tel: ++47 2293 5947; Fax: ++47 2293 4580; \\ E-mail: per.seglen@labmed.uio.no
}

Received 11.2.00; revised 21.3.00; accepted 3.4.00

Edited by A Columbano

\begin{abstract}
The protein phosphatase-inhibitory algal toxins, okadaic acid and microcystin-LR, induced overphosphorylation of keratin and disruption of the keratin cytoskeleton in freshly isolated rat hepatocytes. In hepatocyte cultures, the toxins elicited DNA fragmentation and apoptotic cell death within $24 \mathrm{~h}$. All these toxin effects could be prevented by the grapefruit flavonoid, naringin. The cytoprotective effect of naringin was apparently limited to normal hepatocytes, since the toxininduced apoptosis of hepatoma cells, rat or human, was not prevented by the flavonoid. Cell Death and Differentiation (2000) $7,739-746$.
\end{abstract}

Keywords: apoptosis; cytoprotectant; flow cytometry; hepatocyte; hepatoma; hepatotoxin

Abbreviations: DMEM, Dulbecco's modified Eagle's medium; EDTA, ethylenediamine tetraacetic acid; EGTA, ethylene glycolbis( $\beta$-aminoethyl ether)- $N, N, N^{\prime}, N^{\prime}$-tetraacetic acid; K8, keratin 8; $\mathrm{K} 18$, keratin 18; PBS, phosphate-buffered saline; PBS-T, PBS with $0.1 \%$ Tween-80; SDS, sodium dodecyl sulfate; TUNEL, terminal deoxynucleotidyl transferase-mediated dUTP-digoxigenin nick end-labeling

\section{Introduction}

Toxins produced by marine and freshwater algae represent a significant environmental hazard. Okadaic acid, synthesized by dinoflagellates and concentrated in mussels, is a major causative agent of diarrhetic shellfish poisoning, ${ }^{1,2}$ and microcystins, made by blue-green algae which sometimes infest drinking water supplies, are strong hepatotoxins that have caused sickness and death in both humans and animals. ${ }^{3-6}$ In isolated rat hepatocytes, algal toxins have been shown to induce a disruption of various cytoskeletal elements ${ }^{7-10}$ as well as to elicit apoptotic cell death. ${ }^{11}$

Since the algal toxins are protein phosphatase inhibitors which cause overphosphorylation of cellular proteins, ${ }^{1,12}$ some of their biochemical effects can be antagonized by protein kinase inhibitors. For example, the inhibition of hepatocytic autophagy and endocytosis by okadaic acid can be antagonized by protein kinase-inhibitory flavonoids as well as by specific inhibitors of $\mathrm{Ca}^{2+} /$ calmodulindependent protein kinase $1 \mathrm{I}^{13-15}$ Furthermore, the flavonoid, PD-98059, a potent inhibitor of MAP kinase kinases, ${ }^{16}$ was recently found to prevent the okadaic acid-induced death of cultured rat neurons, ${ }^{17}$ suggesting a potential cytoprotective role for this class of compounds. Here we show that another flavonoid, naringin (the bitter-tasting component of grapefruit), can protect rat hepatocytes against toxin-induced overphosphorylation and disruption of the keratin cytoskeletal network, as well as against toxininduced apoptotic cell death. Interestingly, the protective effect of naringin may be confined to normal hepatocytes, since the toxin-induced apoptosis of human or rat hepatoma cells was unaffected by the flavonoid.

\section{Results and discussion}

\section{Prevention of toxin-induced cytoskeletal changes by naringin}

Both okadaic acid and microcystin-LR induced a disruption of the keratin intermediate filament organization in freshly isolated rat hepatocytes, as revealed by fluorescence microscopy of keratin immunostained cells (Figure 1). Whereas control cells displayed a diffuse filamentous keratin network (Figure 1A), more than $90 \%$ of cells treated for $1 \mathrm{~h}$ with okadaic acid (30 nM; Figure 1B) or microcystin ( $1 \mu \mathrm{M}$; Figure $1 \mathrm{C}$ ) had their keratin network collapse into numerous small spherical aggregates. The presence of naringin $(100 \mu \mathrm{M})$ completely prevented these toxin-induced changes (Figure 1D).

Immunoblotting with a site-specific antibody which recognized phosphoserine 33 on keratin $18^{22}$ showed that this site became overphosphorylated in cells treated with okadaic acid or microcystin (Figure 1E). The keratin phosphorylation was more sensitive to okadaic acid than to microcystin, probably relating to the fact that okadaic acid is internalized more directly by hepatocytes than microcystin, ${ }^{14,23}$ the latter apparently requiring uptake by bile acid transporters. ${ }^{24,25}$ The high potency of okadaic acid would suggest a type $2 \mathrm{~A}$ protein phosphatase as the enzyme being inhibited by the toxin; the type 1 phosphatases being several orders of magnitude less sensitive to okadaic acid. ${ }^{1}$

Naringin completely prevented the keratin overphosphorylations induced by either okadaic acid or microcystin (Figure 1E). This flavonoid has no direct effect on either basal or okadaic acid-suppressed protein phosphatase 2A activity under cell-free conditions (our unpublished results), 

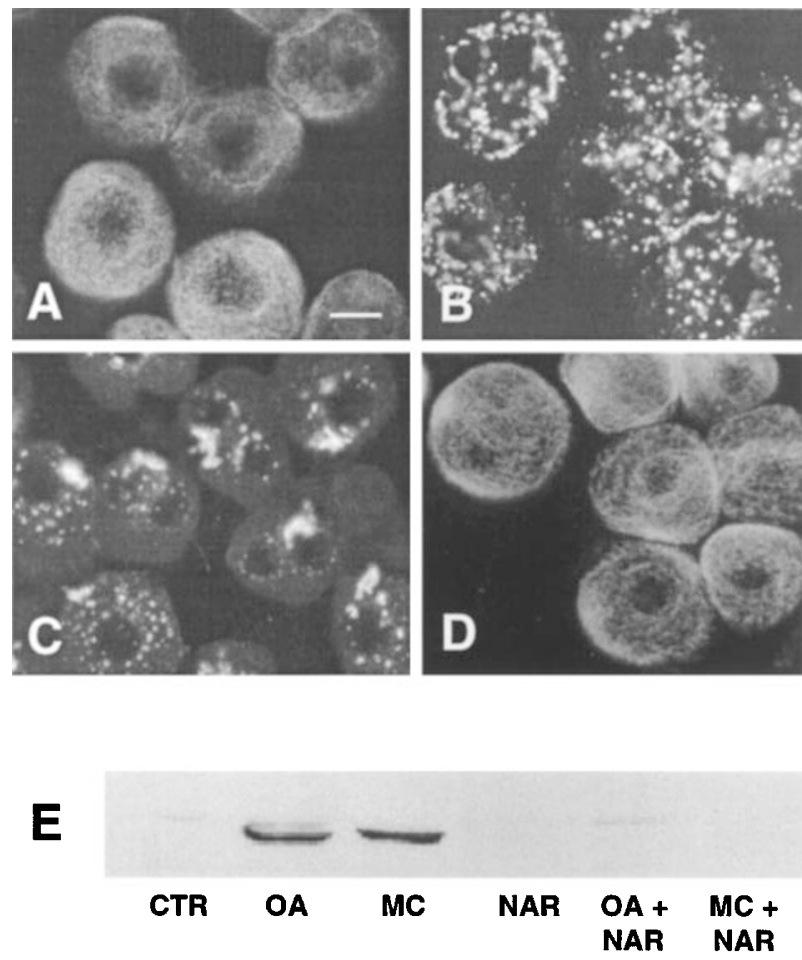

Figure 1 Prevention, by naringin, of toxin-induced phosphorylation and disruption of the hepatocytic keratin cytoskeleton. Freshly isolated rat hepatocytes were incubated for $1 \mathrm{~h}$ at $37^{\circ} \mathrm{C}$ with the additions indicated. (A-D) The cells were sedimented onto glass slides, fixed in $100 \%$ methanol and processed for indirect immunofluorescence staining of keratin, using a monoclonal antibody against $\mathrm{K} 8$ as described in Materials and Methods. (A) No additions (control); (B) Okadaic acid, $30 \mathrm{nM}$; (C) Microcystin-LR, $1 \mu \mathrm{M}$; (D) Okadaic acid+naringin, $100 \mu \mathrm{M}$ (cells treated with microcystin plus naringin, or with naringin alone, likewise looked like control cells). (E) The cells were lysed in an SDS-containing buffer, and their proteins separated by electrophoresis in $10 \%$ SDS-polyacrylamide gels. Immunoblotting was performed using a mouse monoclonal antibody against K18-pSer33. Lane 1, no additions (control); lane 2, okadaic acid, $30 \mathrm{nM}$; lane 3, microcystin-LR, $1 \mu \mathrm{M}$; lane 4, naringin, $100 \mu \mathrm{M}$; lane 5, okadaic acid+naringin; lane 6 , microcystin-LR+naringin

suggesting that it inhibits the phosphorylation of keratin rather than promoting its dephosphorylation. Many other flavonoids have been shown to be effective and specific protein kinase inhibitors. ${ }^{26-28} \mathrm{~A}$ number of protein kinases have been shown, under cell-free conditions, to be able to phosphorylate keratins 8 and 18; these include MAP kinase, the cyclin-dependent kinase Cdc2, S6 kinase, AMP-activated protein kinase, $\mathrm{Ca}^{2+} /$ calmodulin-dependent protein kinase $\mathrm{II}$, protein kinase $\mathrm{C}$ and protein kinase A. ${ }^{22,29-31}$ The putative naringin-sensitive kinase has not yet been identified, but at least none of the latter three kinases seem to be directly affected by the flavonoid (our unpublished results).

\section{Protection, by naringin, of normal rat hepatocytes against toxin-induced apoptotic cell death}

To investigate whether the toxin-antagonistic effect of naringin might include a prevention of toxin-induced apoptotic cell death, ${ }^{11}$ short-term cultures of rat hepatocytes were established. ${ }^{32}$ DNA fragmentation and DNA strand breaks, two of the hallmarks of apoptosis, were detected by a flow-cytometric TUNEL method. ${ }^{20}$ Hepatocytes differ from most other cell types in that the majority of their nuclei are polyploid, ${ }^{33}$ but the stoichiometric staining of DNA with Hoechst 33258 readily resolved normal nuclei (R1 gate) of diploid (2N), tetraploid $(4 \mathrm{~N})$ or octoploid $(8 \mathrm{~N})$ DNA content as well as some $2 \mathrm{~N} / 4 \mathrm{~N}$ aggregates in the $6 \mathrm{~N}$ position (Figure 2A). In control hepatocyte cultures, only $5-10 \%$ of the nuclei were recorded as apoptotic (R2 gate), i.e., with fragmented DNA (subdiploid DNA content) or DNA strand breaks (high FITC immunofluorescence). In contrast, cultures treated with $30 \mathrm{nM}$ okadaic acid for $24 \mathrm{~h}$ had $30-40 \%$ apoptotic nuclei (Figure 2B). The apoptosis was verified by the ability of okadaic acid to induce extensive internucleosomal DNA cleavage in the hepatocytes, giving rise to a 'DNA ladder' in agarose gels (Figure 2C). Furthermore, a nonspecific inhibitor of apoptotic caspases, zVAD.fmk, ${ }^{34}$ was able to suppress the apoptosis completely (results not shown).

To check that the toxin-induced apoptosis led to cell death, and not just to DNA damage, okadaic acid-treated hepatocyte cultures were examined in the light microscope, using morphological evaluation and staining with trypan blue to distinguish intact cells from dead and dying cells. As shown in Figure 2D, okadaic acid caused extensive, dosedependent hepatocyte death. At $100 \mathrm{nM}$ okadaic acid, nearly all cells were dead after $24 \mathrm{~h}$ of treatment. Most of the dead cells detached from the culture substratum. High doses of microcystin had similar lethal effects (results not shown).

The toxin-induced morphological changes associated with the apoptotic death of cultured hepatocytes, such as surface blebbing, cell rounding and detachment, and nuclear fragmentation as detected by Hoechst staining, were completely preventable by inclusion of naringin in the culture medium (Figure $3 \mathrm{~A}-\mathrm{H}$ ). The cells remained attached to the culture dish, retaining their normal flattened shape and round, intact nuclei. The ability of naringin to suppress toxin-induced apoptosis was most clearly illustrated by TUNEL analysis: whereas $300 \mathrm{nM}$ microcystin induced almost $50 \%$ apoptosis in $24 \mathrm{~h}$, no effect of the toxin was observed in the presence of naringin (Figure 3I). Similarly, the dose-dependent apoptosis induced by okadaic acid was strongly suppressed by naringin (Figure $3 \mathrm{~J}$ ), as was okadaic acid-induced cell death (Table 1). A number of other flavonoids, tested at concentrations up to $300 \mu \mathrm{M}$ (genistein, apiin, rhoifolin, neohesperidin) failed to antagonize okadaic acid-induced apoptosis (results not shown). The protective effect of naringin is thus unlikely to reflect the general antioxidant properties of flavonoids, in which regard naringin is among the least active. ${ }^{35,36} \mathrm{~A}$ protein kinase-inhibitory effect of naringin would seem more probable, in analogy with the ability of PD-98059, a flavonoidic MAP kinase inhibitor, ${ }^{16}$ to prevent okadaic acid-induced death of cultured rat neurons. ${ }^{17}$ PD-98059, incidentally, had no cytoprotective effect on hepatocytes (results not shown).

Disruption of the hepatocellular cytoskeleton has been postulated to be a direct cause of death in microcystin- 

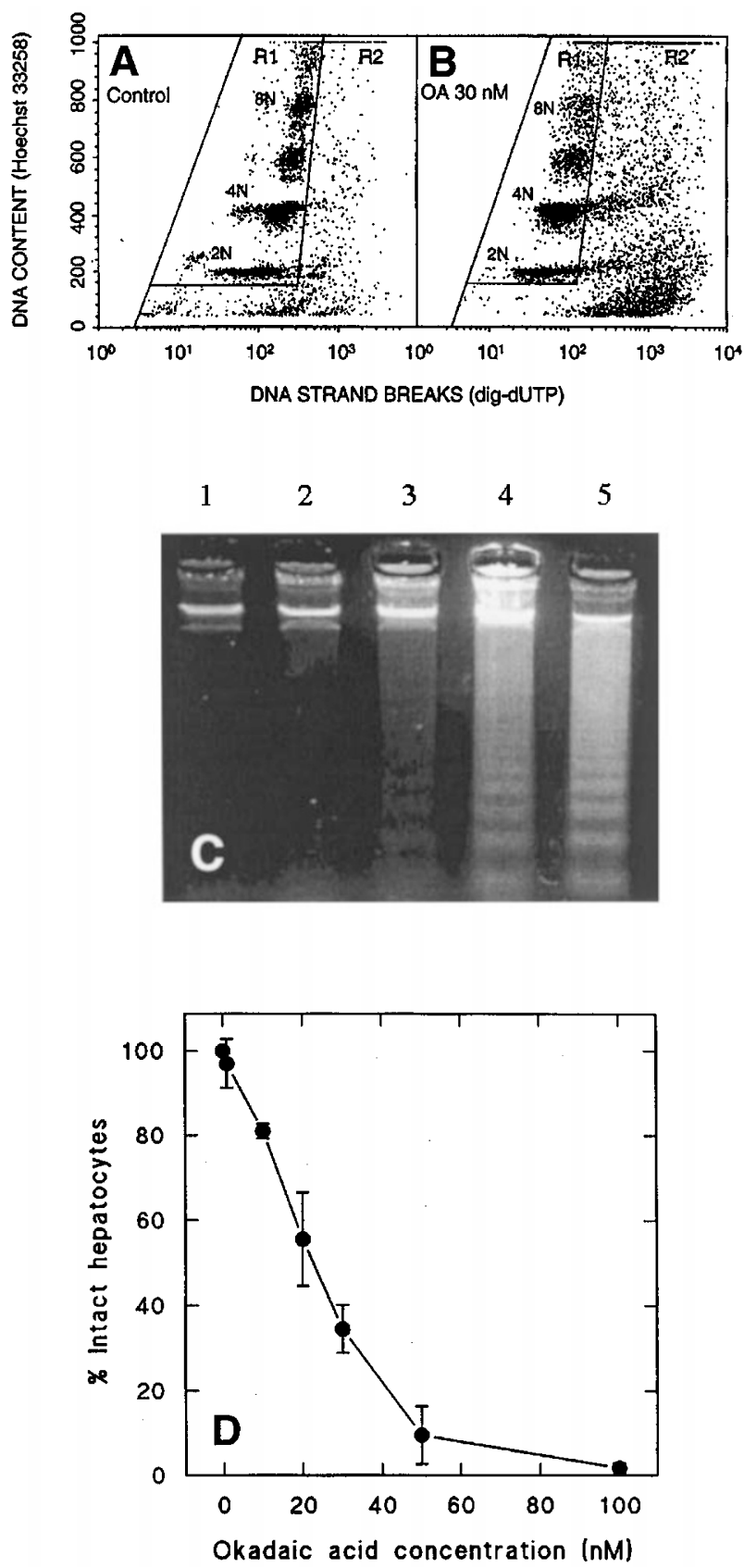

Figure 2 Okadaic acid-induced DNA fragmentation and apoptotic cell death of cultured rat hepatocytes. (A-B) Rat hepatocytes were cultured for $24 \mathrm{~h}$ at $37^{\circ} \mathrm{C}$ in the absence $(\mathbf{A})$ or presence $(\mathbf{B})$ of $30 \mathrm{nM}$ okadaic acid. Nuclei were isolated by a citrate-detergent method, and DNA strand breaks end-labeled in situ with digoxigenin-dUTP using terminal transferase (TUNEL method). The nuclei were stained with anti-digoxigenin-FITC (to detect DNA strand breaks) and Hoechst 33258 (to quantify DNA), and analysed by two-parametric flow cytometry. The analysis gates were set to discriminate normal nuclei of various ploidies (gate R1) from apoptotic nuclei with DNA loss and/or DNA strand breaks (gate R2). (C) DNA, extracted from hepatocytes cultured for $24 \mathrm{~h}$ at various okadaic acid concentrations, was subjected to electrophoresis in a $1.4 \%$ agarose gel. The gel was stained with SYBR ${ }^{\mathrm{TM}}{ }^{\mathrm{G}}$ reen and photographed under ultraviolet illumination. Lane 1, control; lane 2, $1 \mathrm{nM}$ okadaic acid; lane $3,10 \mathrm{nM}$ okadaic acid; lane 4, $30 \mathrm{nM}$ okadaic acid; lane 5, $100 \mathrm{nM}$ okadaic acid. (D) Hepatocyte cultures, incubated for $24 \mathrm{~h}$ at the concentration of okadaic indicated, were aspirated to remove detached, dead cells (uniformly staining with trypan blue). The monolayers were then fixed in $70 \%$ ethanol, or examined directly after addition of trypan blue. The number of attached cells in treated rodents, the consequent weakening of cellular mechanical strength and cell-to-cell contacts resulting in hepatic hemorrhage., 87 The relationship between the cytoskeleton and apoptosis is less clear: like other cytoskeletal proteins, keratins are frequently cleaved secondarily to the activation of apoptotic proteinases (caspases), ${ }^{38,39}$ but a role for keratins in anti-apoptotic signaling has also been postulated. ${ }^{40}$ Whether the disruption of the keratin network plays a causal role in the toxin-induced apoptosis of cultured hepatocytes remains to be shown, but at least the parallel effects of naringin on apoptosis and cytokeratin alterations strongly suggest the existence of a common regulatory element.

\section{Inability of naringin to protect hepatoma cells against toxin-induced apoptosis}

Several hepatoma cell lines (the Morris $7800 \mathrm{C}_{1}$ rat hepatoma cells and the human hepatoma cell lines Hep3B and C3A) were found to be as susceptible to okadaic acid-induced apoptotic cell death as were normal rat hepatocytes. Figure $4 A-D$ shows that the toxin caused extensive nuclear fragmentation in Hep3B cells, and Figure 4E demonstrates internucleosomal DNA cleavage ('DNA ladder') in okadaic acid-treated Morris $7800 \mathrm{C}_{1}$ cells. In contrast to okadaic acid, microcystin had no effect on hepatoma cells at any concentration (results not shown), possibly because hepatoma cells tend to lack the bile acid transporters required for cellular microcystin uptake. ${ }^{25}$

Dose-dependent apoptosis was well demonstrated by the TUNEL method both in Morris $7800 \mathrm{C}_{1}$ cells (Figure 4F) and in Hep3B cells (Figure 4G). Surprisingly, naringin, at $100 \mu \mathrm{M}$, did not antagonize okadaic acid in any of the hepatoma cell lines (including the C3A cells, not shown here). Higher naringin concentrations (up to $1 \mathrm{mM}$ ) were equally ineffective, and the use of alternative culture media (including the medium used for hepatocytes) did not alter the results. Naringin sensitivity may thus, like bile acid transport, be a property easily lost in hepatoma cells.

Okadaic acid reduced hepatoma cell viability in very much the same way that it affected normal hepatocytes, and after $24 \mathrm{~h}$ with $30 \mathrm{nM}$ okadaic acid the fraction of intact cells was reduced to about $30 \%$ both in hepatocyte cultures and in cultures of Morris $7800 \mathrm{C}_{1}$ hepatoma cells (Table 1). In contrast to its protection of normal hepatocytes, naringin did not detectably preserve the viability of the hepatoma cells. It is thus clear that this flavonoid cytoprotectant prevents the death of normal rat liver cells, but not the death of cancer cells derived from the same tissue.

The cytoprotective effect of naringin may be tissuespecific: it did not prevent the okadaic acid-induced death

25 microscope fields was counted, and their morphology scored as either intact or abnormal (damaged/dead cells). The number of intact cells remaining in the culture dish was expressed as per cent of the corresponding number in okadaic acid-free control cultures (about 900 cells per 25 fields). Each value is the mean $+S$.E. or range of $2-3$ experiments 


\section{Phase contrast}
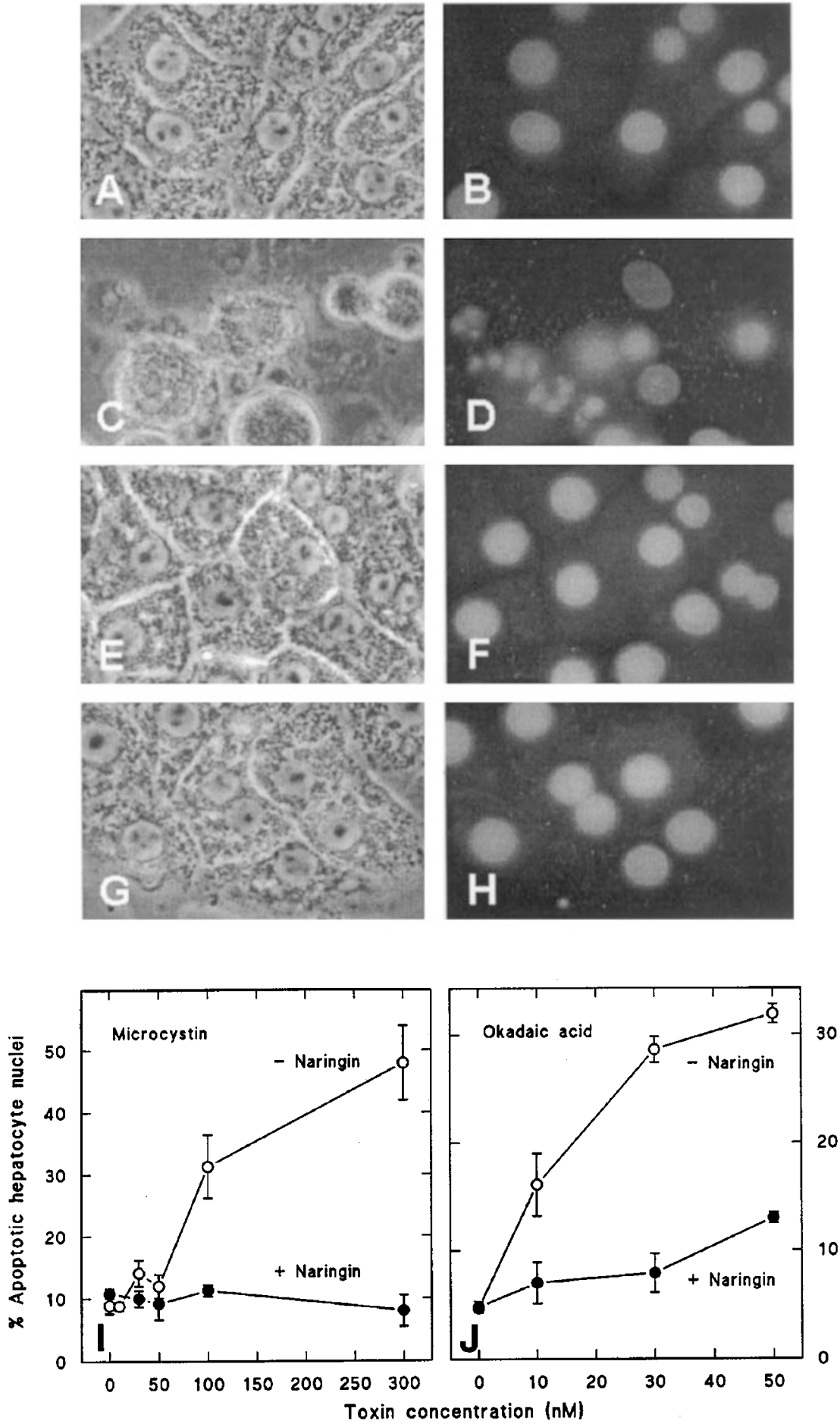

Figure 3 Naringin protects normal rat hepatocytes against toxin-induced apoptotic death. $(\mathbf{A}-\mathbf{H})$ Hepatocytes were cultured for $24 \mathrm{~h}$ under the following conditions: (A,B) control; (C,D) okadaic acid, $30 \mathrm{nM} ;(\mathbf{E}, \mathbf{F})$ naringin, $100 \mu \mathrm{M} ;(\mathbf{G}, \mathbf{H})$ naringin+okadaic acid. The cells were stained supravitally with Hoechst 33258 $(2.5 \mu \mathrm{g} / \mathrm{ml}) ; 10 \mathrm{~min}$ later the brightly blue-fluorescent nuclei of live cells were examined in the fluorescence microscope (right) and compared with the cellular morphology as seen under phase contrast (left). $\times 540$. (I-J) Hepatocytes were cultured for $24 \mathrm{~h}$ with microcystin-LR (I) or okadaic acid $(\mathbf{J})$ at the concentration indicated, in the absence $(O)$ or presence $(-)$ of naringin, $100 \mu \mathrm{M}$. Nuclei were isolated by a citrate-detergent technique, labeled according to the TUNEL method, and analyzed by two-parametric flow cytometry. Apoptotic nuclei have been scored as per cent of the total number analyzed (10000). Each value is the mean \pm S.E. or range of 2-5 experiments 
Table 1 Selective protection, by naringin, against okadaic acid-induced cell death in normal hepatocytes vs hepatoma cells

\begin{tabular}{lcc}
\hline & \multicolumn{2}{c}{$\%$ Intact cells } \\
Treatment & $\begin{array}{c}\text { Normal } \\
\text { hepatocytes }\end{array}$ & $\begin{array}{c}\text { Hepatoma } \\
\text { cells }\end{array}$ \\
\hline None (control) & $100(3)$ & $100(3)$ \\
Naringin $(100 \mu \mathrm{M})$ & $85 \pm 3(3)$ & $92 \pm 7(3)$ \\
Okadaic acid $(30 \mathrm{nM})$ & $30 \pm 4(3)^{\star}$ & $27 \pm 2(4)^{\star}$ \\
Okadaic acid+naringin & $75 \pm 5(3) \dagger$ & $34 \pm 7(4)$ \\
\hline
\end{tabular}

${ }^{*} P<0.001$ vs control; $\dagger P<0.05$ vs okadaic acid. Normal rat hepatocytes or Morris $7800 C_{1}$ rat hepatoma cells were kept in culture for $24 \mathrm{~h}$ before the addition of naringin $(100 \mu \mathrm{M})$ or okadaic acid (30 $\mathrm{nM}$; $30 \mathrm{~min}$ later) as indicated. After another $24 \mathrm{~h}$, the cultures were fixed in $70 \%$ ethanol, and the number of adherent cells with normal morphology was counted in 25 microscope fields and expressed as per cent of the number of cells in control dishes. Each value is the mean $\pm S$.E. of the number of independent experiments given in parentheses

of cultured rat neurons, ${ }^{17}$ nor could it preserve the cytoskeletal integrity and viability of isolated rat colonocytes undergoing detachment-induced apoptosis. ${ }^{41}$ Conversely, the synthetic flavonoid, PD-98059, protected neurons but not hepatocytes. The possibility of developing tissue-specific cytoprotective flavonoids is intriguing, since such agents might conceivably be of interest not only for protection against environmental toxins, but also for protection of normal tissues against degenerative changes occurring under various pathological conditions. There should be no shortage of candidates among the thousands of structurally different flavonoids present within the plant kingdom. ${ }^{42}$

\section{Materials and Methods}

\section{Materials}

Dulbecco's modified Eagles medium (DMEM), Ham's F-10 and F12 media, penicillin/streptomycin, fungizone, garamycin, genistein, microcystin-LR, anti-I-PPLO, calf and horse serum were all purchased from Gibco BRL (Paisley, Scotland, UK). Digoxigenin11-dUTP, terminal transferase and anti-digoxigenin-fluorescein Fab fragments were obtained from Boehringer Mannheim $\mathrm{GmbH}$ (Germany). Monoclonal mouse antibody against rat keratin 8 (K8) was a generous gift from Prof. Normand Marceau (University of Laval, Quebec, Canada). The monoclonal phosphokeratin antibody against K18-pSer33 (Clone IB4) was purchased from Clontech (Palo Alto, CA, USA); this antibody is no longer commercially available. Okadaic acid was obtained from Moana Bioproducts Inc. (Hawaii, USA) or Alexis Biochemicals (Läufelfingen, Switzerland); PD-98059 from New England Biolabs (Beverly, MA, USA); apiin and neohesperidin from Extrasynthase SA (Lyon, France). Naringin, rhoifolin and all other biochemicals were obtained from Sigma Chem. Co. (St. Louis, MO, USA). The Morris $7800 \mathrm{C}_{1}$ hepatoma cell line was kindly provided by Dr. Øystein Spydevold (Institute for Medical Biochemistry, University of Oslo, Norway); other cell lines (Hep3B, C3A) were purchased from the American Type Culture Collection (Manassas, VA, USA).

\section{Cell culture}

Normal, primary hepatocytes were isolated from male Wistar rats $(200-250 \mathrm{~g})$ by two-step collagenase perfusion ${ }^{18}$ and cultured at $37^{\circ} \mathrm{C}$ on a substratum of adsorbed collagen at a cell density of $8.5 \cdot 10^{4}$ cells $/ \mathrm{cm}^{2}$. The culture medium was a $1: 1$ mixture of DMEM and Ham's F-12, supplemented with L-glutamine (2 mM), epidermal growth factor $(5 \mathrm{nM})$, insulin $(67 \mathrm{nM})$, dexamethasone $(26 \mathrm{nM})$ and garamycin $(3 \mu \mathrm{M})$. The $7800 \mathrm{C}_{1}$ Morris rat hepatoma cells were plated at a density of $1.5 \cdot 10^{4}$ cells $/ \mathrm{cm}^{2}$ in Ham's F-10 supplemented with $10 \%$ horse serum, $3 \%$ calf serum, penicillin $(50 \mathrm{U} / \mathrm{ml})$, streptomycin $(50 \mu \mathrm{g} / \mathrm{ml})$, fungizone $(2.5 \mu \mathrm{g} / \mathrm{ml})$ and anti-I-PPLO $(50 \mu \mathrm{g} / \mathrm{ml})$. Hep3B and C3A human hepatoma cells were cultured in DMEM with $10 \%$ fetal calf serum, at a plating density of $1.3 \cdot 10^{4}$ cells $/ \mathrm{cm}^{2}$. After an attachment period of $2.5-3 \mathrm{~h}$, the medium was changed, and incubation continued for another 24 or $48 \mathrm{~h}$.

\section{Immunofluorescence microscopy}

Cells incubated for $1 \mathrm{~h}$ at $37^{\circ} \mathrm{C}$ were washed three times (1600 rev/ $\min$ for 5 min at $4^{\circ} \mathrm{C}$ ) and resuspended in suspension buffer to obtain a cell density of about $0.3 \cdot 10^{6}$ cells $/ \mathrm{ml}$. The cells were then sedimented (750 rev/min for $5 \mathrm{~min}$ ) onto microscope slides using a Cytospin cytocentrifuge (Shandon Scientific Ltd., Cheshire, UK) before being fixed in $100 \%$ methanol for $10 \mathrm{~min}$ at $-20^{\circ} \mathrm{C}$ and washed three times with phosphate-buffered saline (PBS; $\mathrm{pH} 7.5$ ). For visualization of keratin intermediate filaments, cells were overlaid for $30 \mathrm{~min}$ with a monoclonal mouse antibody against rat K8 diluted 1:1000 in PBS. The cells were then washed three times in PBS and incubated with a fluorescein-conjugated anti-mouse antibody diluted 1:40 in PBS for $30 \mathrm{~min}$ in the dark. Finally the cells were washed three times in PBS and mounted in Mowiol (Hoechst, Frankfurt, Germany). Antibody incubations were performed in a humid chamber at room temperature. The cells were examined in a Nikon Optiphot microscope and photographed with a Kodak TMAX 400 film.

\section{Gel electrophoresis and immunoblotting}

Samples for immunoblotting were lysed in sodium dodecyl sulfate (SDS) buffer (20 mM Tris- $\mathrm{HCl}$, pH 7.2, 5 mM EGTA, $10 \mathrm{mM}$ sodium pyrophosphate, $0.4 \%$ SDS, $1 \mathrm{mM}$ phenylmethylsulfonylfluoride, $10 \mu \mathrm{g} /$ $\mathrm{ml}$ leupeptin, $10 \mu \mathrm{g} / \mathrm{ml}$ antipain). Whole cell extracts were diluted $1: 1$ in double strength SDS-gel-loading buffer (single-strength SDS-gelloading buffer; $50 \mathrm{mM}$ Tris- $\mathrm{HCl}$; $\mathrm{pH} 6.8,1 \mathrm{M}$ mercaptoethanol, $2 \%$ SDS, $0.1 \%$ bromophenol blue, $10 \%$ glycerol) and separated by $10 \%$ SDS-polyacrylamide gel electrophoresis. ${ }^{19}$ The separated proteins were transferred to nitrocellulose paper using a semi-dry transfer unit (Bio-Rad Laboratories) and blocked by an overnight incubation at $4^{\circ} \mathrm{C}$ with $5 \%$ dry milk in PBS. The membranes were then washed three times for 5 min in PBS with $0.1 \%$ Tween-20 (PBS-T) and incubated for $2 \mathrm{~h}$ at room temperature with a phosphospecific antibody against keratin 18 (K18-pSer33), diluted 1:30 in PBS-T. After washing three times for $5 \mathrm{~min}$ in PBS-T, the membranes were incubated for $30 \mathrm{~min}$ at room temperature with anti-mouse-horseradish peroxidase, diluted $1: 2000$ in PBS-T. The membranes were then washed twice in PBS-T and once in PBS before they were finally visualized by chemiluminescence using the ECL Western Blotting Detection Kit (Amersham). 
Phase contrast
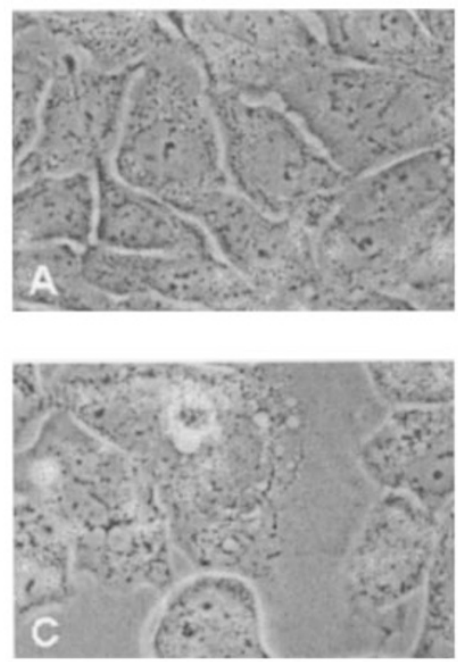

Hoechst
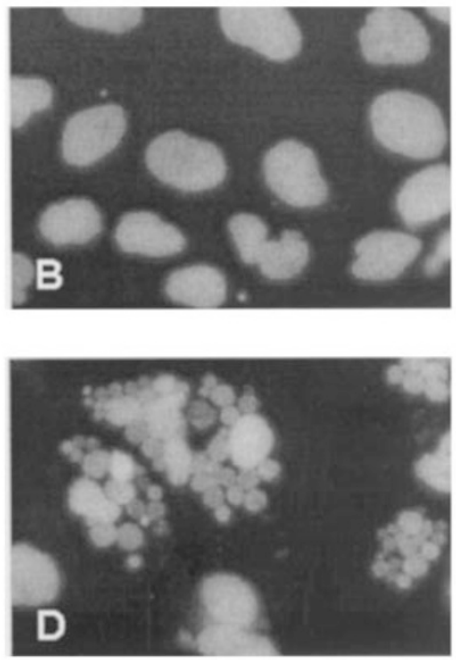

456
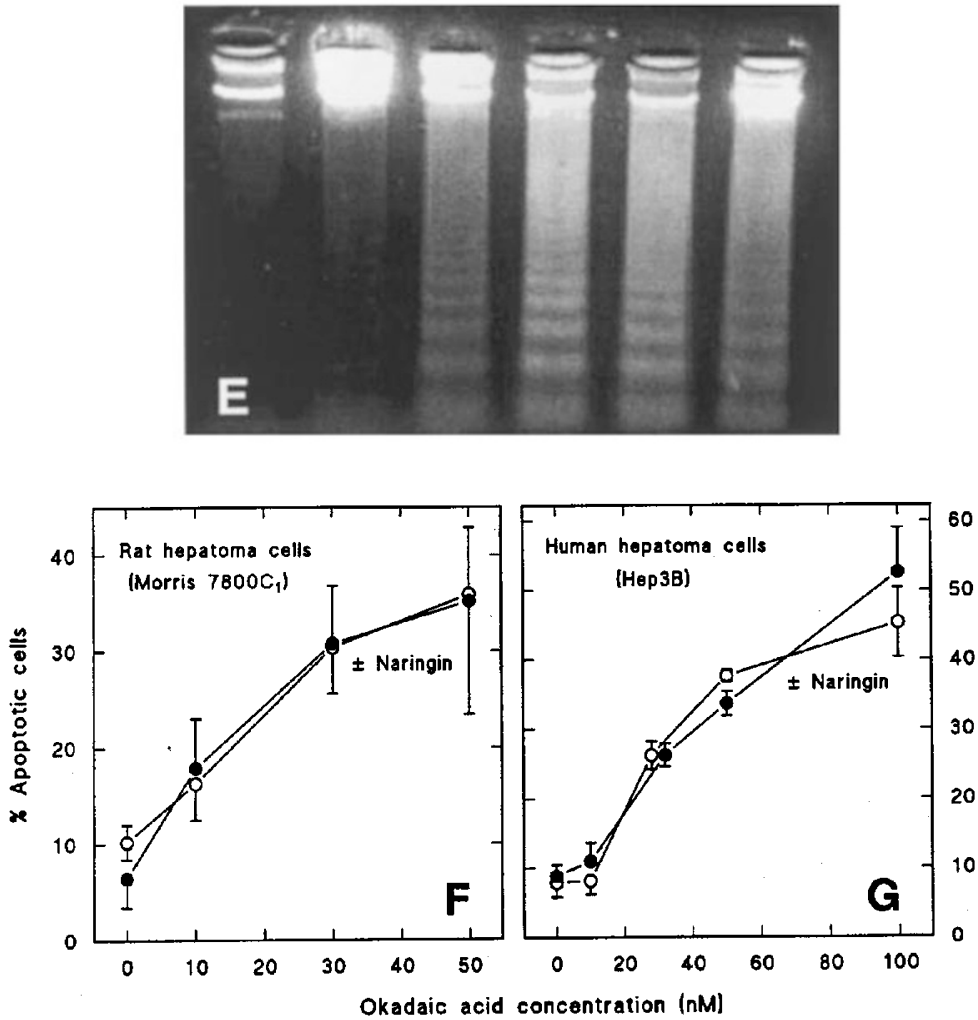

Figure 4 Lack of protective effect of naringin against toxin-induced apoptosis in rat and human hepatoma cells. (A-D) Hep3B human hepatoma cells were cultured for $24 \mathrm{~h}$ in the absence $(\mathbf{A}, \mathbf{B})$ or presence $(\mathbf{C}, \mathbf{D})$ of $30 \mathrm{nM}$ okadaic acid, then stained with the fluorescent vital stain Hoechst $33258(2.5 \mu \mathrm{g} / \mathrm{ml})$. Left, phase contrast; right, fluorescent microscopy. Notice extensive nuclear fragmentation in okadaic acid-treated cells (D). $\times 590$. (E) Morris $7800 \mathrm{C}_{1}$ rat hepatoma cells were cultured for $24 \mathrm{~h}$ with up to $100 \mu \mathrm{M}$ okadaic acid. DNA was extracted and subjected to electrophoresis in a $1.4 \%$ agarose gel, stained with SYBR ${ }^{\text {TM }} \mathrm{Green}$, and photographed under ultraviolet illumination. Lane 1, control; lane 2, okadaic acid, $1 \mathrm{nM}$; lane 3, okadaic acid, $10 \mathrm{nM}$; lane 4, okadaic acid, $15 \mathrm{nM}$; lane 5 , okadaic acid, $30 \mathrm{nM}$; lane 6, okadaic acid, $100 \mathrm{nM}$. (F-G) Morris $7800 \mathrm{C}_{1}$ rat hepatoma cells $(\mathbf{F})$, or Hep3B human hepatoma cells $(\mathbf{G})$ were cultured for $24 \mathrm{~h}$ with okadaic acid at the concentration indicated, in the absence $(\mathrm{O})$ or presence $(\mathbf{O})$ of naringin, $100 \mu \mathrm{M}$. The cells were dislodged by trypsinization, labeled according to the TUNEL method, and analyzed by flow cytometry. Apoptotic cells are scored as per cent of the total number analyzed (10000). Each value is the mean $\pm S$.E of $3-5$ experiments 


\section{Measurement of apoptosis by DNA labeling (TUNEL)}

Whole hepatoma cells, or nuclei from cultured hepatocytes (which cannot be dissociated into single cells), prepared by a citratedetergent method, were fixed in $1 \%$ paraformaldehyde for 15 min on ice and permeabilized in $70 \%$ ethanol at $-20^{\circ} \mathrm{C}$. DNA strand breaks were end-labeled by the TUNEL method, using incubation with terminal transferase to incorporate digoxigenin-11-dUTP, which was then stained with anti-digoxigenin-FITC. ${ }^{20}$ Staining with Hoechst 33258 was used to detect total DNA and nuclear fragmentation. Cells or nuclei were analyzed by two-parametric flow cytometry in a FACScan flow cytometer (Becton Dickinson), using the gate settings shown in Figure 1; cells, nuclei with DNA strand breaks (right-hand part of cytogram) or fragmented DNA (lower part) were collectively defined as apoptotic, and scored as the percentage of total.

\section{Agarose gel analysis of DNA fragmentation}

Cell samples were harvested from the culture dishes, and apoptotic DNA fragments isolated according to Hermann et al. ${ }^{21}$ Briefly, cells were washed once in PBS and pelleted by centrifugation before being lysed with lysis buffer (1\% NP-40 in $20 \mathrm{mM}$ EDTA, $50 \mathrm{mM}$ Tris- $\mathrm{HCl}$, $\mathrm{pH} 7.5 ; 60 \mu \mathrm{l} /$ cell sample) and recentrifuged for $5 \mathrm{~min}$ at $1600 \times \mathrm{g}$. The supernatants were collected and the extraction was repeated with the same amount of lysis buffer. The supernatants were then brought to $1 \%$ SDS and treated with RNase A (final concentration $5 \mathrm{mg} / \mathrm{ml}$ ) for $1-2 \mathrm{~h}$ in a water bath at $37^{\circ} \mathrm{C}$ followed by proteinase $\mathrm{K}$ (final concentration $2.5 \mathrm{mg} / \mathrm{ml}$ ) for at least $2 \mathrm{~h}$ at $37^{\circ} \mathrm{C}$. Finally, $0.5 \mathrm{vol} 10 \mathrm{M}$ ammonium acetate was added and the DNA precipitated with $2.5 \mathrm{vol}$ ethanol at $-20^{\circ} \mathrm{C}$ overnight. The resuspended nuclei were subjected to the same treatment as the supernatants, and were used as controls of the complete recovery of apoptotic DNA fragments. The DNA fragments were separated in a $1.4 \%$ agarose gel stained with SYBR ${ }^{\mathrm{TM}}$ Green and photographed under ultraviolet illumination.

\section{Cellular viability}

Cellular viability was measured by examining the cultures in the microscope, scoring the adherent cells (in 25 microscopical fields per culture dish) as morphologically normal (intact) or grossly abnormal (dead or dying; verified by trypan blue staining). Detached cells were always dead. The number of intact cells in toxin-treated cultures was expressed as per cent of the number in comparable control cultures from the same experiment. To assess alterations in nuclear morphology, the cell cultures were stained supravitally with Hoechst33258 ( $10 \mathrm{~min}$ at $37^{\circ} \mathrm{C}, 24 \mathrm{~h}$ after seeding), and the brightly bluefluorescent nuclei were examined in live cells in the fluorescence microscope.

\section{Acknowledgments}

This work has been generously supported by the Norwegian Cancer Society. The skilful technical assistance of Tone Granseth and Lena Haugland Moen is gratefully acknowledged.

\section{References}

1. Bialojan $C$ and Takai $A$ (1988) Inhibitory effect of a marine-sponge toxin, okadaic acid, on protein phosphatases. Specificity and kinetics. Biochem. J. 256: $283-$ 290

2. Cohen P, Holmes CFB and Tsukitani Y (1990) Okadaic acid: A new probe for the study of cellular regulation. Trends Biochem. Sci. 15: 98-102

3. Jochimsen EM, Carmichael WW, An JS, Cardo DM, Cookson ST, Holmes CE, Antunes MB, de Melo Filho DA, Lyra TM, Barreto VS, Azevedo SMand Jarvis WR (1999) Liver failure and death after exposure to microcystins at a hemodialysis center in Brazil. New Eng. J. Med. 338: 873-878

4. Hawkins PR, Runnegar MTC, Jackson ARB and Falconer IR (1985) Severe hepatoxicity caused by the tropical cyanobacterium (blue-green alga) Cylindrospermopsis raciborskii (Woloszynska) Seenaya and Subba Raju isolated from a domestic water supply reservoir. Appl. Environ. Microbiol. 50: $1292-1295$

5. Runnegar MTC, Falconer IR, Buckley T and Jackson ARB (1986) Lethal potency and tissue distribution of ${ }^{125} \mathrm{I}$-labelled toxic peptides from the blue-green alga Microcystis aeruginosa. Toxicon 24: 506-509

6. Carmichael WW (1994) The toxins of cyanobacteria. Sci. Am. 270: 78-86

7. Eriksson JE, Paatero GIL, Meriluoto JAO, Codd GA, Kass GEN, Nicotera P and Orrenius $S$ (1989) Rapid microfilament reorganization induced in isolated rat hepatocytes by microcystin-LR, a cyclic peptide toxin. Exp. Cell Res. 185: $86-$ 100

8. Falconer IR and Yeung DSK (1992) Cytoskeletal changes in hepatocytes induced by Microcystis toxins and their relation to hyperphosphorylation of cell proteins. Chem.-Biol.. Interact. 81: 181-196

9. Ohta T, Nishiwaki R, Yatsunami J, Komori A, Suganuma M and Fujiki H (1992) Hyperphosphorylation of cytokeratins 8 and 18 by microcystin-LR, a new liver tumor promoter, in primary cultured rat hepatocytes. Carcinogenesis 13: $2443-$ 2447

10. Blankson H, Holen I and Seglen PO (1995) Disruption of the cytokeratin cytoskeleton and inhibition of hepatocytic autophagy by okadaic acid. Exp. Cell Res. 218: $522-530$

11. Bøe R, Gjertsen BT, Vintermyr OK, Houge G, Lanotte M and Døskeland SO (1991) The protein phosphatase inhibitor okadaic acid induces morphological changes typical of apoptosis in mammalian cells. Exp. Cell Res. 195: $237-246$

12. HaysteadTAJ, Sim ATR, Carling D, Honnor RC, Tsukitani Y, Cohen P and Hardie DG (1989) Effects of the tumor promoter okadaic acid on intracellular protein phosphorylation and metabolism. Nature 337: 78-81

13. Holen I, Gordon PB and Seglen PO (1992) Protein kinase-dependent effects of okadaic acid on hepatocytic autophagy and cytoskeletal integrity. Biochem. J. 284: $633-636$

14. Holen I, Gordon PB and Seglen PO (1993) Inhibition of hepatocytic autophagy by okadaic acid and other protein phosphatase inhibitors. Eur. J. Biochem. 215: $113-122$

15. Gordon PB, Holen I and Seglen PO (1995) Protection, by naringin and some other flavonoids, of hepatocytic autophagy and endocytosis against inhibition by okadaic acid. J. Biol. Chem. 270: 5830-5838

16. Dudley DT, Pang L, Decker SJ, Bridged AJ and Saltiel AR (1995) A synthetic inhibitor of the mitogen-activated protein kinase cascade. Proc. Natl. Acad. Sci. USA 92: $7686-7689$

17. Rundén E, Seglen PO, Haug F-M, Ottersen OP, Wieloch T, Shamloo M and Laake JH (1998) Regional selective neuronal degeneration after protein phosphatase inhibition in hippocampal slice cultures: Evidence for a MAP kinase-dependent mechanism. J. Neurosci. 18: 7296-7305

18. Seglen PO (1976) Preparation of isolated rat liver cells. Meth. Cell Biol. 13: 2983

19. Laemmli UK (1970) Cleavage of structural proteins during the assembly of the head of bacteriophage T4. Nature 227: 680-685

20. Cain K, Inayat-Hussain SH, Couet C, Qin HM and Oberhammer FA (1996) A novel method for detecting apoptosis shows that hepatocytes undergo a time dependent increase in DNA cleavage and chromatin condensation which is augmented after TGF- $\beta_{1}$ treatment. Cytometry 23: $312-321$

21. Herrmann M, Lorenz HM, Voll R, Grunke M, Woith W and Kalden JR (1994) A rapid and simple method for the isolation of apoptotic DNA fragments. Nucleic Acids Res. 22: 5506-5507 
22. Ku NO and Omary MB (1997) Phosphorylation of human keratin 8 in vivo at conserved head domain serine 23 and at epidermal growth factor-stimulated tail domain serine 431. J. Biol. Chem. 272: 7556-7564

23. Mellgren G, Vintermyr OK, Bøe R and Døskeland SO (1993) Hepatocyte DNA replication is abolished by inhibitors selecting protein phosphatase $2 \mathrm{~A}$ rather than phosphatase 1. Exp. Cell Res. 205: 293-301

24. Runnegar MTC, Gerdes RG and Falconer IR (1991) The uptake of the cyanobacterial hepatotoxin microcystin by isolated rat hepatocytes. Toxicon 29: 43-51

25. Eriksson JE, Grönberg L, Nygard S, Slotte JP and Meriluoto JA (1990) Hepatocellular uptake of ${ }^{3} \mathrm{H}$-dihydromicrocystin-LR, a cyclin peptide toxin. Biochim. Biophys. Acta 1025: 60-66

26. Ogawara H, Akiyama T, Watanabe S, Ito N, Kobori M and Seoda Y (1989) Inhibition of tyrosine protein kinase activity by synthetic isoflavones and flavones. J. Antibiotics 42: 340-343

27. Ferriola PC, Cody V and Middleton E (1989) Protein kinase C inhibition by plant flavonoids. Biochem. Pharmacol. 38: 1617-1624

28. Jinsart W, Ternai B and Polya GM (1992) Inhibition of rat liver cyclic AMPdependent protein kinase by flavonoids. Hoppe-Seyler's Z. Physiol. Chem. 373: 205-211

29. Yano T, Tokui T, NishiY, Nishizawa K, Shibata M, KikuchiK, Tsuiki S, Yamauchi T and Inagaki M (1991) Phosphorylation of keratin intermediate filaments by protein kinase $\mathrm{C}$, by calmodulin-dependent protein kinase and by CAMPdependent protein kinase. Eur. J. Biochem. 197: 281-290

30. Ku NO and Omary MB (1994) Identification of the major physiologic phosphorylation site of human keratin 18: Potential kinases and a role in filament reorganization. J. Cell Biol. 127: 161-171

31. Velasco G, Del Pulgar TG, Carling D and Gunmán M (1998) Evidence that the AMP-activated protein kinase stimulates rat liver carnitine plamitoyltransferase I by phosphorylating cytoskeletal components. FEBS Lett. 439: 317-320

32. Mossin L, Blankson H, Huitfeldt H and Seglen PO (1994) Ploidy-dependent growth and binucleation in cultured rat hepatocytes. Exp. Cell Res. 214: 551 560
33. Gerlyng P, Stokke T, Huitfeldt HS, Stenersen T, Danielsen HE, Grotmol T and Seglen PO (1992) Analytical methods for the study of liver cell proliferation. Cytometry 13: $404-415$

34. Hirsch T, Marchetti P, Susin SA, Dallaporta B, Zamzami N, Marzo I, Geuskens M and Kroemer G (1997) The apoptosis-necrosis paradox. Apoptogenic proteases activated after mitochondrial permeability transition determine the mode of cell death. Oncogene 15: 1573-1581

35. Affany A, Salvayre R and Douste-Blazy $L$ (1987) Comparison of the protective effect of various flavonoids against lipid peroxidation of erythrocyte membranes (induced by cumene hydroperoxide). Fundam. Clin. Pharmacol. 1: 451-457

36. Ratty AK and Das NP (1988) Effects of flavonoids on nonenzymatic lipid peroxidation: structure-activity relationship. Biochem. Med. Metab. Biol. 39:69 79

37. Miura GA, Robinson NA, Lawrence WB and Pace JG (1991) Hepatotoxicity of microcystin-LR in fed and fasted rats. Toxicon 29: 337-346

38. Caulín C, Salvesen GS and Oshima RG (1997) Caspase cleavage of keratin 18 and reorganization of intermediate filaments during epithelial cell apoptosis. J. Cell Biol. 138: $1379-1394$

39. Ku NO, Liao J and Omary MB (1997) Apoptosis generates stable fragments of human type I keratins. J. Biol. Chem. 272: 33197-33203

40. Miao JY, Araki S, Kaji K and Hayashi H (1997) Integrin beta4 is involved in apoptotic signal transduction in endothelial cells. Biochem. Biophys. Res. Commun. 233: $182-186$

41. Berven G, Sætre F, Halvorsen K and Seglen PO (2000) Effects of the diarrhetic shellfish toxin, okadaic acid, on cytoskeletal elements, viability and functionality of rat liver and intestinal cells. Toxicon, in press

42. Brandi ML (1992) Flavonoids: biochemical effects and therapeutic applications. Bone and Mineral 19: S3-S14 